\title{
Trystes Cosmologiques: When Lévi-Strauss Met the Astrologers
}

\section{Graham Douglas}

Abstract: In October 1969 the famous anthropologist Claude Lévi-Strauss gave an interview to the well-known French astrologers André Barbault and Dr JeanPaul Nicola for the astrology magazine L'Astrologue. To the author's knowledge this interview has never been discussed in academic journals, and is here published for the first time in English translation. It is considered in the context of its time, and of the issues discussed: the Surrealist movement, which had an important influence on Lévi-Strauss's early work; the structure of the unconscious mind; and the question of causation in astrology.

At the end of the interview Lévi-Strauss suggested a joint project with his interviewers to study the interpretations of serious astrologers as a way of understanding how their minds work. According to Dr Nicola, the suggestion was never developed because in his opinion there was no chance of getting astrologers to agree on how to go about it. In the last 20 years however, several theses have been devoted to similar projects.

In 1969 the anthropologist Claude Lévi-Strauss gave an interview to the French astrology magazine L'Astrologue, a year after talking to the surrealist magazine L'Archibras. ${ }^{1}$ While the latter interview is little-known among academic researchers today, the former seems to have disappeared below the horizon - Emmanuelle Loyer who recently published a 900-page biography of Lévi-Strauss makes no mention of it, and Philippe Descola, one of Lévi-Strauss's students and now professor at the Collège de France,

\footnotetext{
${ }^{1}$ The original interview in French appeared in the journal L'Astrologue 9 (Autumn 1970): pages 1-6. I am grateful to André Barbault for permission to publish my translation, and to both interviewers for their replies to my queries. Claude LéviStrauss, 'Voix Off, Claude Courtot entretien avec Claude Lévi-Strauss', L'Archibras 3 (1968).

Graham Douglas, 'Trystes Cosmologiques: When Lévi-Strauss met the astrologers', Culture and Cosmos, Vol. 18, no. 2, Spring/Summer 2014, pp. 143166. www.CultureAndCosmos.org
} 
expressed surprise to me that he would have done such a thing. ${ }^{2}$ Both interviews are indexed on the site http://las.ehess.fr/index.php?1337, which shows that Lévi-Strauss was rather a prolific subject.

The interview was nearly 50 years ago, but the interviewers have been able to clarify some points regarding the context. In a letter to me, which he dated by the position of the sun in the zodiac, Andre Barbault said that it was his initiative to write to the famous anthropologist, admitting that he was surprised to receive a reply. And Dr Jean-Pierre Nicola told me that the published interview was considerably shortened by editing out his argument with Lévi-Strauss over causality. He says that the latter did eventually accept that there might be causal effects operating. ${ }^{3}$

At the time that he gave these interviews Lévi-Strauss was at the peak of his fame and even notoriety, according to his biographer: Playboy magazine ran an article about structuralism - which Lévi-Strauss responded to - and the trainer of a football team said he wanted to use structuralist principles. ${ }^{4}$

Since Lévi-Strauss was advised by the astronomer Jean-Claude Pecker, a virulent opponent of all things astrological, it would seem unlikely that he would have an interest in contemporary astrology, but as Descola pointed out, Lévi-Strauss was always a man with an unusual degree of curiosity and open-mindedness. ${ }^{5}$

And we can see that Lévi-Strauss would be open to astrology in general terms from his remarks in Tristes Tropiques:

We gave up sun worship a long time ago and we have lost the habit of associating the points of the compass with magic qualities, colours, and virtues. But... we cannot prevent the major astronomical and meteorological

${ }^{2}$ Emmanuelle Loyer, Lévi-Strauss (Paris: Flammarion, 2015); Emmanuelle Loyer, personal communication, October 2015; Descola email to Graham Douglas July 2015.

3 Letter to Graham Douglas dated 1CN15 meaning 23 June 2015.

${ }^{4}$ Loyer, Lévi-Strauss, p. 577.

5 Descola email to Graham Douglas July 2015; Pecker dismissed the careful statistical analysis by the Gauquelins as 'biased and of no value', Bulletin de la Société Astronomique de la France, July 1974, cited by Barbault in The Value of Astrology: from ancient knowledge to today's reality, English translation (London: The Astrological Association, 2014), p. 91. For a detailed account of the controversy over the Gauquelin work, see Suitbert Ertel and Ken Irving, The Tenacious Mars Effect. (London: Urania Trust, 1996). And for the most up-to-date survey of research into astrology, see Geoffrey Dean, Arthur Mather, David Nias and Rudolf Smit, Tests of Astrology (Amsterdam: Astrologie in Onderzoek, 2016).

Culture and Cosmos 
phenomena conferring almost imperceptible but ineradicable properties on certain areas.' 6

And:

But are they really superstitions? I see these preferences rather as denoting a kind of wisdom which savage races practiced spontaneously and the rejection of which, by the modern world, is the real madness. ${ }^{7}$

Although Lévi-Strauss was still being widely celebrated as one of France's premier intellectuals in 1969, classical structuralism was coming under sustained attack from many quarters. Post-structuralism had begun in 1967 with the publication of Derrida's first book, and in 1968 a collection of critical articles was published under the title Qu'est-ce-que le Structuralisme?. ${ }^{8}$ Over the next five years these attacks became quite virulent, and Lévi-Strauss was considered to have been supplanted from his position as France's foremost intellectual by Foucault and Lacan. Between the two interviews he had suffered serious health problems.'

Of his two interviewers, André Barbault and Jean-Pierre Nicola, the former is better known, through his books and from editing the journal L'Astrologue for many years. He also interviewed quite a number of wellknown figures about their views on astrology for his journal. ${ }^{10}$ Two of the interviewees, Guy Michaud and Gilbert Durand, were well-known academics at French universities who nevertheless were pleased to talk

6 Lévi-Strauss, Tristes Tropiques (Harmondsworth: Penguin Modern Classics, 2011), p. 122.

${ }_{7}^{7}$ Lévi-Strauss, Tristes Tropiques, p. 123.

${ }^{8}$ Jacques Derrida, De la Grammatologie (Paris: Les Éditions de Minuit, 1967); Oswald Ducrot, Tzvetan Todorov, Dan Sperber, Moustafa Safouan, and François Wahl, Qu'est-ce-que le Structuralisme? (Paris: Seuil, 1968).

${ }^{9}$ Cited by Patrick Wilcken, Claude Lévi-Strauss: The Poet in the Laboratory (London: Bloomsbury, 2010), p. 299.

${ }^{10}$ Henry Miller, in L'Astrologue 16 (Winter 1971): pp. 193-5; André Bréton in L'Astrologue (1978), reproduced in English with an introduction by Nicholas Campion in Culture and Cosmos 6, no. 2 (Autumn/Winter, 2002): pp. 45-56; C. G. Jung May 1954, published in L'Astrologue 8 (Winter 1969): pp. 193-6; the literature professor Guy Michaud in L'Astrologue 21 (Spring 1973): pp. 1-5), who had written several books about surrealism; plus short responses from Jean Cocteau in L'Astrologue 12 (Winter 1970): pp. 1-2); Werner Heisenberg, a refusal in L'Astrologue 20 (Winter 1972): pp. 1-2. Another literature professor, Gilbert Durand, wrote an article Astrologie et son Langage, in L'Astrologue 45/46 (Spring 1979): pp. 44-55. 
openly about their beliefs in or practice of astrology. Other reports surface in the Internet of interest in astrology by French academics. Lucien Malavard, a science professor at the Sorbonne, mentioning primitive classification, is reported as saying that astrology was the original social science before the name existed. ${ }^{11}$ Nicola also has authored a number of books, obtained a PhD at the University of Hawaii (2004), and founded his own school of Astrologie Conditionnaliste. ${ }^{12}$ In his journal Astrologique he interviewed an astronomer, Hubert Reeves, who at least considered astrology to have a worthy place in the history of science, although as Nicola pointed out to me this was before Reeves had developed his career. $^{13}$

Nicola took a lesser part in the interview, and his work has not been translated into English, although a number of articles are available on his website. But the two men have broken off all collaboration and, according to Patrice Guinard, their continuing disputes are legendary in French astrological circles. ${ }^{14}$

During his interview with Barbault, Lévi-Strauss mentions that he was working on a study which showed that a series of myths with their varying structures can be related to astronomical phenomena. This corresponds to the work he published in his next book The Naked Man, the final volume of his series Mythologiques, where there is astronomical data relating to the constellations of the Pleiades and Orion.

I will first present the interview and then discuss some of the issues which arise and consider the interview in a contemporary context.

${ }^{11}$ Jack Mandon, 'L'Astrologue: Une Femme...', Agora (15 April 2008): 'Lucien Malavard, prof. de sciences à la Sorbonne: «Je pense que les anciens ont fait en quelque sorte des sciences humaines avant la lettre par l'intermédiaire de l'astrologie. Ils ont ainsi bâti une classification des êtres, une manière d'y voir plus clair dans les comportements humains. Pour ma part, je serais tenté de situer l'astrologie à côté des sciences humaines, un peu plus loin... », available at http://www.agoravox.fr/tribune-libre/article/l-astrologie-une-femme-38659 [accessed 20 June 2016).

${ }_{12}$ Nicola's $\mathrm{PhD}$ is on 'Globalite en psychologie analytique et astrologie conditionaliste' (University of Hawaii, 2004). His many publications can be consulted at http://www.astroariana.com/_Jean-Pierre-Nicola_html [accessed 10 June 2016].

${ }^{13}$ See Astrologique 4 (August 1976): pp. 1-5. Email from Pierre Nicola, May 2016.

${ }^{14}$ See Guinard's CURA website, which is also a mine of information for serious researchers into all aspects of astrology, at http://cura.free.fr/docum/10astrof.html, entry no. 21 for Nicola.

Culture and Cosmos 
Interview with Claude Lévi-Strauss

Professor at the Collège de France. Conducted in Paris, 6 October 1969, with André Barbault and Jean-Pierre Nicola. Translated from the French by Graham Douglas.

C. L-S.: First I will tell you a little story which goes back a long way. On the day I received my agregation to teach Philosophy - I received the news one morning - that same afternoon I wanted to do something which in my eyes symbolized my liberation from those long years of study. So I went to the Chacornac bookshop beside the Seine, and bought a book about astrology. ${ }^{15}$ Not at all because I believed in it or wanted to dedicate myself to studying it, but because in my opinion it was the symbol of a great intellectual construction which was worth quite as much as those whose study I had been obliged to concentrate on for years and years. I still have it. I don't think that [buying it] was anything very important, but it has been for me a kind of magical gesture, if you like.

A. B.: Do you have a settled opinion against astrology? Are you constrained by the fact that it is a creation of the [human] mind at the stage of magical thinking, if you follow me?

C. L-S.: Yes, considering that the magical mentality appeals to all sorts of mechanisms and schemes which are true of any kind of thinking. An opinion against... frankly, if you asked me whether I believe in it, I would either say 'no', or rather give you a more nuanced opinion. Not long ago it happened that one of your colleagues sent me my horoscope, - and I believe it was someone serious, because he did not give in to the temptation to make any kind of predictions for the future. It contained a whole collection of reflections relevant to my life and my character; but all told, there was nothing that a mind with a little sensitivity and intelligence could not have taken from reading my books. So, if I had to reconstruct what he was able to do in such a case, I suppose that he began from some rather vague impressions, because he had read some of my books. Not being a specialist in anthropology, he did not enter into the details - he had felt all that from outside - and then, in order to organise it he resorted to a scheme, a sort of canvas, and since this canvas is an extremely precise structure which obeys certain rules typical of all 'canvases' of this kind, that helped him to crystallize some things which he

${ }^{15}$ The Chacornac bookshop was also the home of Barbault's journal L'Astrologue for many years. 
had perceived in a rather confused fashion. Then, from this base, if you wish, in presenting things in this way, yes, that seems to me to be completely understandable and normal. If, on the other hand it is a question of predicting what will happen in the life of an individual, well then I would have a lot of reservations to make...

A. B.: This schema, which is an astral structure, in your eyes does it have a meaning of its own?

C. L-S.: You are asking a question which is very difficult to answer. Any scheme of organisation, whatever it might be, has an intrinsic value. I'm not convinced - I don't know any more about it - that this kind has any value unique to itself: or one which is any greater than the lines on the hand, or the [Tarot] cards. In all these cases, it seems to me that it is a question of schema which impose very rigorous constraints on the interpreter; even if they are arbitrary constraints, they force [the interpreter] to think, and to make an intellectual effort, which for them is productive.

A. B.: For our part, we go further, because we conceive an objective relation between the astral data and the psychological universe of the individual.

C. L-S.: Your position is very understandable. But for an outsider it raises fundamental problems. The first is that it is hard to understand how; it seems to me that for that hypothesis to be plausible it would have to be able to produce a certain number of intermediate mechanisms between the stars and man. The second [problem], is that in the same place at the same time, approximately, there is not just one person born, and what is true for one cannot be true for the other.

J-P. N.: But on the one hand, the common background to these beings that are similarly 'starred' [have similar astrological charts], derives from an analogical structure, which does not necessarily lead to identical outcomes; and on the other hand the astronomical canvas implies some properties distances, speeds, rhythms... - which are in themselves, structured, structural and structuring. This organisation of the cosmos orders the values of an individual more than it organises the strategy of the interpreter. These are real structures!

C. L-S. What you call real structures, are the structures of your mind, which come into play at the time that you make your studies, and the structures of your mind are also those of all minds. I am not surprised that there can be and there are coincidences (...). Astrology is an extremely ancient science - the first - and the persistent influence that it exercises on the human mind comes precisely from what it [the mind] became interested in very early on, in the 
truly interesting things, in other words in correspondences. ${ }^{16}$ Only, you see, from the moment when one makes the effort to establish systems of relationships intrinsic to some domains or some worlds, you establish intrinsic systems of relationships to the astronomical universe, intrinsic to the human universe, and so on. Because it is the same mind which has worked in one framework and in the other, it is unavoidable that it perceives some homologies between these systems of relationships. I am very ready to accept that. The real difficulty begins if one attempts to establish a causal relation, if I can put it like this, between one level of relationships and another, and personally, I don't believe that it is necessary in any case. I don't feel the need to do that.

A. B.: It is what we experience in the context of the 'symbolist' school of astrology, despite the probability of a physical substrate to an astral influence. It seems normal to us that the earliest societies were naturally in tune with cyclic processes in correspondence with astronomical phenomena. ${ }^{17}$

C. L-S.: A correspondence undeniably: because they were people who were extremely attentive to certain types of phenomena, and because they were attentive to them, of course that played a role in their lives. I am working at the moment on unravelling an entire mythology, and showing that the relations between different myths can be explained by the astronomical references of each one to a whole series of phenomena, which between themselves are in a relationship based on transformation. They are not like this objectively; they are like this for the human mind which perceives them. So, the Moon Spots and the Sunspots are in correspondence, because they are dark marks within a bright perimeter, while the conjunction of two stars with the sun at its Heliacal Rising, these are bright marks outside of the perimeter of a dark background; and then one goes on to perihélions, and peri-sélènes, antihélions, and a whole list of things of this kind, in a marvellous series. Then you can show that the place of each myth in relation to any other can be determined through these astronomical references, which - they too - can be put into an objective relationship, inasmuch as they offer some intrinsic characteristics which put them into correlation or opposition one with another. That does not mean of course, that these astronomical phenomena have exercised a causal kind of influence over the minds which constructed the myths, much less on their heroes [of the myths]. They have simply

\footnotetext{
${ }^{16}$ In the French, the original 'rapports' could also be translated as 'relations'; it is impossible to decide, but 'correspondences' is a term used by Lévi-Strauss in describing primitive classification, while astrologers use it to describe the correspondence of microcosm with macrocosm.

17 The 'symbolist' school is the one developed by Barbault, but the term is not used outside France, elsewhere his approach would be recognised as typical of 'psychological astrology'.
} 
constructed a system, and this system, from the point when it was constructed reveals itself as working and productive.

At bottom, all systems are working and productive, because man can only think with systems. Astrology has been a great system, because it has helped man to think for thousands of years.

J-P. N.: Can it still help humanity to think?

C. L-S.: Perhaps, still, yes to a certain extent. I don't doubt - not in the same sense which you have in mind - for me, because it is a subject of study, and astrology as a subject of study can greatly enlarge our vision of man and his mental mechanisms.

J-P. N.: In any case, there is no absolute contradiction for us between a symbolic expression and physical influence.

C. L-S.: You are not obliged, it seems to me, to immediately think of a causal relationship. You could very well imagine that the astronomical configurations on the one hand, and let's say the psychological configurations on the other hand - simplifying enormously - arise from something else which determines both of them together.

A. B.: We are no less obliged in this to rely on physical phenomena which influence us, such as the phases of the Moon and the tides in the oceans.

C. L-S.: It is interesting that you mention tides, because in the end what we call circadian rhythms are rhythms which are partly biological, (and we can consequently consider that they have an incontestable psychological role), and partly physical. At the same time, you can conceive that they have a relationship which we don't understand well, or that we don't understand at all, with the rhythms of much longer periodicity which are those of cosmic phenomena; in that way you would have a means of getting round the chasm that separates the stars from the destinies of individuals.

J-P. N.: Yes, through rhythms.

A.B.: The fact is we don't know why. This is what made André Bréton say that astrology holds one of the highest secrets of the world.

C. L-S.: I knew André Bréton well - we were very close for a period of time; but I won't go as far as him. I wouldn't say that it holds [secrets] - but it is perhaps one of the signs that secrets exist which we don't understand, and I feel impelled to say, that we will doubtless never understand.

You know that there is a great piece of work that we can do together, because astrology would seem to be a subject of study, if not a study [in itself], in any case one of the most fascinating subjects of study. In order to know how astrologers think, how they reason, how they analyse, we [would] use some treatises and manuals of the kind that I went to buy a long time ago. But there would be a whole study to be made that would seem to me to be much more fascinating. Starting from concrete documents, making use of the

Culture and Cosmos 
considerable quantity of horoscopes skilfully interpreted by high quality astrologers - with the aim of attempting to reconstruct the way in which their minds work, how they engage with it. This is an ethnological task, for a psychologist who doubles as a historian of science; but still it would be necessary to know a lot of astronomy as well.

Lévi-Strauss: the turn to anthropology

Anthropology had emerged as a discipline in Britain during the $19^{\text {th }}$ century, while in France it only separated itself from sociology - which Émile Durkheim had largely established with his Rules of Sociological Method, published in 1885 - during the interwar period. ${ }^{18}$ It was also influenced by French surrealism during this period, which will be discussed later.

In a conversation with Didier Eribon in 1989, Lévi-Strauss again mentions his purchase of an astrology book following his agregation, this time attributing his action simply to a desire to celebrate his freedom and to prove to himself that he still had an independent mind. ${ }^{19}$ In the L'Astrologue interview however, he describes it as a 'magical gesture', which suggests that he had by then read Marcel Mauss's book A General Theory of Magic, even though he was not yet set on the path to becoming an anthropologist.

In The Savage Mind Lévi-Strauss built on the earlier work of Durkheim and Mauss. ${ }^{20}$ Mauss, who was Durkheim's nephew and a much more congenial personality than his uncle, was greatly admired by Lévi-Strauss, and may even have been the first influence leading him towards Social Anthropology. This seems likely since Lévi-Strauss wrote asking Mauss's advice in October 1931, shortly after his agregation, saying he was strongly tempted to study ethnography. ${ }^{21}$ Thus the purchase of the astrology book happened during a crucial period in Lévi-Strauss's life.

In Tristes Tropiques, Lévi-Strauss says that, despite the mixture of motives propelling him towards anthropology, the 'revelation' did not happen until 1933-4 when by chance he came across the book Primitive

18 Émile Durkheim, The Rules of Sociological Method (London: Simon and Schuster, 1982).

12 Didier Eribon, Conversations with Claude Lévi-Strauss, trans. Paul Wissing (Chicago: University of Chicago Press, 1991), p. 10.

${ }^{20}$ Émile Durkheim and Marcel Mauss, Primitive Classification, trans. Rodney Needham (Chicago: University of Chicago Press, 1963). In this book, one of the topics they studied was Chinese astrology. The book is cited by Vilhena, The World of Astrology, pp. 6, 21-22.

${ }^{21}$ Loyer, Lévi-Strauss, p. 115. 
Society by Robert Lowie. ${ }^{22}$ Among his other reasons were a disenchantment with the aridity of the philosophy he was expected to teach, a need for adventure and physical contact with nature and people, and simply as an escape route from his conventional life. ${ }^{23}$

Although Lévi-Strauss had criticised Paul Nizan's book Aden Arabie, he appreciated its author's search for a more authentic way of life than what was offered by French society. It helped to crystallize his belief that nature must be appreciated as it is and not reduced to a theatre for human exploitation. ${ }^{24}$ Earlier than this, both the arts and social sciences were appealing to Lévi-Strauss. While teaching in secondary schools he enjoyed citing Baudelaire, and as a boy had been deeply impressed with Wagner's polyphonic music, which much later he came to recognise as a source of his interest in the architecture of myth.

\section{Primitive classification and the structure of astrology}

Lévi-Strauss's work in The Savage Mind has been used by the Brazilian researcher Luís Rodolfo Vilhena to analyse the system of astrological symbols, whose conclusions are worth summarising. ${ }^{25}$ Vilhena begins by pointing out that although Durkheim and Mauss had initiated the study of astrology as possessing an autonomous logic, they still viewed it as an inferior stage in the development of the human mind. ${ }^{26}$ In contrast, as is well-known, Lévi-Strauss accorded no logical or developmental priority to modern science over primitive magic. ${ }^{27}$

Vilhena goes on to describe what he calls the synchronic classifications within the astrological symbol system, made up of a variety of oppositions such as Fire/Water and Earth/Air, as well as positive/negative, above/below, masculine/feminine. In addition, there is the ternary system which divides the 12 zodiac signs into Cardinal, Fixed and Mutable types, and the diachronic structuring arising from the passage of the sun from

\footnotetext{
${ }^{22}$ Lévi-Strauss, Tristes Tropiques, p. 59.

${ }^{23}$ Loyer, Lévi-Strauss, p. 91.

${ }^{24}$ Paul Nizan, Aden Arabie (Paris: Rieder, 1931; $2^{\text {nd }}$ edition with introduction by Jean-Paul Sartre, Paris: Editions Maspero, 1960); Loyer, Lévi-Strauss, pp. 91, 121. ${ }^{25}$ Vilhena, Luis Rodolfo, O Mundo da Astrologia: estudo antropológico (Rio de Janeiro: Jorge Zahar Editor, 1990), English translation by Graham Douglas, The World of Astrology: an ethnography of astrology in contemporary Brazil (Ceredigion: Sophia Centre Press, 2014).

${ }^{26}$ Vilhena, The World of Astrology, p. 24.

${ }^{27}$ Lévi-Strauss, La Pensée Sauvage (Paris: Plon, 1962), p. 24, and see Vilhena, The World of Astrology, pp. 23-24.
}

Culture and Cosmos 
each sign to the next during one year. Vilhena acknowledges the usefulness of Lévi-Strauss's distinction between the way that these classification systems work with signs and images derived from immediate experience, in contrast to modern science which derives abstract concepts and seeks structure at a level behind appearances. ${ }^{28}$ Later Vilhena draws attention to the way that astrological structure is maintained, in a similar way to what Lévi-Strauss found in myth, irrespective of the content of its symbols; the Sun and Moon are always seen as a contrasting pair for example. ${ }^{29}$ And, again in line with Lévi-Strauss's analysis of myth, he points out how the astrological system of symbols, although based on a limited number of terms, can yet produce almost infinite possibilities of interpretative combinations. ${ }^{30}$

Vilhena's work is the first full-length sociological analysis of the function of astrological practice in the lives of its contemporary students, and he goes on to point out how modern astrologers, in common with people in non-industrial societies, are concerned to view the human being and the events of their lives as meaningfully structured wholes, and less through the lens of causality or mechanism. He cites Lévi-Strauss remarking that in systems based on dichotomous oppositions, 'everything has a meaning, otherwise nothing has a meaning'. ${ }^{31}$ The sociological context of the practice of astrology has been much studied since then and it will be considered later in relation to the suggestion by Lévi-Strauss in the interview of making a study of astrological interpretations.

Returning to the interview, we see that Lévi-Strauss resists the astrologers' claim that there is an intrinsic meaning in astrology, and says that in his view they have no need of a causal model, since the correspondences that they perceive arise from the structuring of their own minds. This is fully in line with the Structuralist refusal to see cultural phenomena as determined by social or biological ones. ${ }^{32}$

Looking at the book The Value of Astrology, which Barbault considers his 'testament', and has recently been made available in English, his comments on astrology and psychoanalysis accept that astrology originates within the human being, and that what we observe in the world is a

\footnotetext{
${ }^{28}$ Vilhena, The World of Astrology, pp. 27-30.

${ }^{29}$ Vilhena, The World of Astrology, p. 48.

${ }^{30}$ Vilhena, The World of Astrology, p. 52.

${ }^{31}$ Vilhena, The World of Astrology, p. 58; and Claude Lévi-Strauss, La Pensée Sauvage (Paris: Plon, 1962), p. 228.

${ }^{32}$ See http://www.cardiff.ac.uk/socsi/undergraduate/introsoc/durkheim4.html for more on this distinction which goes back to Durkheim [accessed 16 Jun 20160].
} 
projection of that ${ }^{33}$ Barbault cites Jung saying that the personality, being unconscious, cannot be distinguished from the contents of its projections, "which means that to a great extent it is identical to its surroundings'. ${ }^{34}$ However Barbault also says that 'man, by introjection, astralises himself and assimilates himself into a celestial body', which may have been difficult for Lévi-Strauss to accept, along with the claim that the analogy between the human soul and nature and the constellations was 'how the structuralist seminology ( $\mathrm{sic}$ ) of astrology came about in the universe of the word'. ${ }^{35}$ Whatever this 'introjection' means, any correspondences between the psyche and patterns projected onto the heavens do not require the movements of the planets to somehow correlate with movements in the psyche, yet this is clearly what Barbault intends since he devotes a whole chapter to astrological forecasting. ${ }^{36}$ Lévi-Strauss states explicitly in the interview that he does not accept forecasting, nor would he go along with Barbault's attempts to employ Freudian developmental language to explain the meanings of the planets - 'Mars (the oral-sadistic stage energy, according to the Freudians' vision), ${ }^{37}$

\section{Lévi-Strauss and Jung}

Reading the interview today, it seems strange that Jung was not discussed, given how central his psychology has become to modern astrology. ${ }^{38}$

33 André Barbault, The Value of Astrology: from ancient knowledge to today's reality (London: The Astrological Association, 2014), translated by Kate Johnston from L'Astrologie Certifée (Paris: Éditions du Seuil, 2006), Translator's preface, and pp. 163-165.

${ }^{34}$ Barbault, Value, p. 167, citing Jung, 'The Roots of Consciousness', no page or publication details given.

35 Barbault, Value, p. 166. The French word 'verbe' can be translated as 'word', 'voice' or 'verb'. The meaning of this sentence is quite obscure, but it is possible that 'verb' is a better translation because Barbault was familiar with the work of Gilbert Durand, who described his work as 'structuralist' and emphasized that the archetypes were active entities like verbs in grammar. Barbault has confirmed to me that he was indeed influenced by Durand's thought in this passage, (email dated '8 degrees Gemini, 2016'). See also Mable Franzone, 'L'Imaginaire: une approche de la pensée de Gilbert Durand', trad. Marilyne Renard, Esprit Critique 5, no. 3 (Summer 2003): p. 7, available at www.espritcritique.fr/0503/esp0503article05.html [accessed 2 July 2016].

${ }^{36}$ Barbault, Value, pp. 118-159.

${ }^{37}$ Barbault, Value, p. 173.

${ }^{38}$ Dr Nicola has confirmed that Jung was not mentioned at all during their conversation, email to Graham Douglas May 2016.

Culture and Cosmos 
However, at the time of the interview the only work that had incorporated Jungian psychology into astrology in the English language was Dane Rudhyar's Astrology of the Personality, originally published in 1936. Most of the influential books on 'Jungian astrology' did not appear in English until the 1970s.

Lévi-Strauss said that Freud's psychoanalysis immediately appealed to him, by confirming his own distaste for dry logical categories that were 'no more than a gratuitous intellectual game', and that the oppositional categories of philosophy such as rational and irrational did not exist in that form. Instead he saw that meaning was a more important category, and one which was intimately emotional. ${ }^{39}$ But Lévi-Strauss's disapproval of Jung's formulation of the archetypes of the collective unconscious, and his dislike of Jung's 'mysticism' are well-known, although he made few comments in print. ${ }^{40}$

Both Jung and Lévi-Strauss were deeply interested in the unconscious mind, and the resemblances between their respective structural analyses have been claimed to be more than coincidence. Thus D'Aquili quotes a long section from Structural Anthropology, pointing out that both the archetypes of the collective unconscious (Jung's term), and the unconscious mind (Lévi-Strauss's term) were conceived of as empty structures, which only became active when an emotionally charged situation brought their structuring influence to bear upon the personal issues in play for an individual. ${ }^{41}$ And D'Aquili goes on to remark on the extraordinary resemblance of this passage to statements from Jung's work from twenty or more years earlier. For example, talking about certain 'inherited psychic factors', 'universal dispositions of the mind', 'which can also be described as categories analogous to the logical categories which are always and everywhere present...' he says that: 'only in the case of our "forms" we are not dealing with categories of reason, but with categories of the imagination'. 'The original structural components of the psyche are of no less surprising a uniformity than those of the physical body. The archetypes are, so to speak, organs of the pre-rational psyche. They are eternally inherited forms and ideas, which have at first no specific content.

\footnotetext{
${ }^{39}$ Lévi-Strauss, Tristes, p. 55.

${ }^{40}$ Lévi-Strauss, Pensée, p. 88.

${ }^{41}$ Eugène d'Aquili, 'The Influence of Jung on the work of Claude Lévi-Strauss', Journal of the History of Ideas 11 (1975): pp. 41-48; and Claude Lévi-Strauss, Structural Anthropology (New York: Anchor, 1963), pp. 198-199.
}

Culture and Cosmos 
The specific content only appears in the course of the individual's life, when personal experience is taken up in precisely these forms ${ }^{42}$

D'Aquili identifies other remarkable parallels in the treatment of kinship by the two authors, noting that Lévi-Strauss published his work three years later than Jung's. ${ }^{43}$

Likewise, the familiar quaternary structure of four elements, which Jung attributed to the collective unconscious, was also a feature which Lévi-Strauss found in certain myths, in one Navajo example the specific contents - Fire, Earth, Wind and Water - are almost identical to those of ancient Greek cosmology. Lévi-Strauss rejected the tendency of Jung to believe in the essential nature of these archetypes, whereas Lévi-Strauss always emphasized that it was structural relations between terms that were the key, not the terms themselves, and further, that it was the relationship of transformation between systems that was the key feature of structuralist analysis. ${ }^{44}$ But Jung's essentialist conception of the archetypes had shifted to something much closer to the structuralist view at least 17 years before Lévi-Strauss attacked him. ${ }^{45}$ Lévi-Strauss's attitude persisted in an interview with George Steiner in August 1966, although according to Staude he later moderated his view, and said that Jung had 'become open to a much more formal structuralist approach' ${ }^{46}$

Richard Gray has reviewed d'Aquili's article, noting that despite these parallels Jung's approach differed from that of Lévi-Strauss in accepting more than purely synchronic abstract data, and moving - as a therapist of course - into subjective areas of the patient's experience. ${ }^{47}$

While it is quite plausible to link the four astrological elements to Jung's four psychological functions, some Jungian astrologers have attempted to identify features in the birth chart with certain archetypes, but

\footnotetext{
${ }^{42}$ Cited in D'Aquili, p. 45, from C. G. Jung, Psyche and Symbol (New York: Doubleday Anchor Books, 1958), pp. 292-293. Italics by D'Aquili.

${ }^{43}$ D'Aquili, p. 47.

${ }^{44}$ Eribon, Conversations, pp. 162-163.

${ }^{45}$ D'Aquili, p. 48.

${ }^{46}$ Cited in J. R. Staude, 'From Depth Psychology to Depth Sociology: Freud, Jung and Lévi-Strauss', Theory and Society 3, no. 3 (1976): pp. 303-338, footnotes 65 and 66; George Steiner, 'A Conversation with Claude Lévi-Strauss', Encounter 26 (August 1966): p. 52.

${ }^{47}$ Richard M. Gray, 'Jung and Lévi-Strauss Revisited: An Analysis of Common Themes', The Mankind Quarterly XXXI, no. 3 (Spring 1991).
}

Culture and Cosmos 
they disagree on how it should be done, or if it should be done at all. ${ }^{48}$ It is also true that Jung tended to speak of archetypes and archetypal images, although the latter are are much more numerous, quite indiscriminately. In an interview in 1954 Jung said that "the "planets" are the gods, symbols of the collective unconscious', without referring to archetypes such as the Persona or the Shadow. ${ }^{49}$

Another important stage in the wider structuralist trajectory - although his work was not translated into English until 1958, and French in 1965 was Vladimir Propp's analysis of the Russian folktale.$^{50}$ Lévi-Strauss was not impressed by the application of structuralist approaches to literary analysis, and treated Roland Barthes' work almost with contempt. ${ }^{51}$ But it can be argued that Greimas's development of Propp's work on the structure of narratives based on a group of six actants, has a more direct connection with astrology. ${ }^{52}$ Roles such as the Hero, the Desired Object, the Helper and the Obstacle seem to have some similarity with the astrological archetypes of Mars, Venus, Jupiter and Saturn respectively, while Greimas's Sender and Receiver plausibly suggest the active Sun and the receptive Moon. ${ }^{53}$

Gilbert Durand proposed a scheme in which the planets and zodiac signs are grouped with various archetypal images on the basis of a concept of symbolism rooted in the main postures and actions of the human body. ${ }^{54}$

48 See Maggie Hyde, Jung and Astrology (London: Aquarian Press/Thorsons, 1992).

49 Jung responded in writing in May 1954 to a questionnaire by André Barbault and Jean Carteret, a transcript of his replies was published in Barbault's journal, L'Astrologue 8 (Winter 1969): pp. 193-196, and an English version is included in C. G. Jung and Gerhard Adler, C.G. Jung Letters, trans. R. F. C. Hull (London: Routledge, 1976), Vol. 2, pp. 175-7.

${ }^{50}$ V. I. Propp, Morphology of the Folktale (Leningrad, 1928; $2^{\text {nd }}$ revised edition, Austin: University of Texas Press, 1958).

${ }^{51}$ Loyer, Lévi-Strauss, pp. 580-583.

${ }^{52}$ A. J. Greimas was a French-Lithuanian who developed a structuralist analysis of semantics, using what became known as the Semantic Square, derived from the Logical Square of Aristotle. For more see Terence Hawkes, Structuralism and Semiotics (Abingdon: Routledge, 1977), pp. 87-95.

${ }^{53}$ Graham Douglas, Physics, Astrology and Semiotics (published by the author, 1983); 'Greimas's Semiotic Square and Greek and Roman Astrology', Semiotica 114, nos. 1 and 2 (1997): pp. 1-19.

${ }^{54}$ Gilbert Durand, Les Structures Anthropologiques de l'Imaginaire: introduction à l'archetypologie (Paris: Dunod, 1992). See also: M. Maffesoli, ed., La Galaxie 
Greimas rejected Durand's approach since it views symbols as determined by a base in the organism, and cannot therefore be considered a structuralist method. ${ }^{55}$ On the other hand, Durand's approach seems quite in tune with the cognitive semantics school, in which bodily schema are seen as central to image making, and Jung acknowledged a similarity between archetypes and innate animal behaviours. ${ }^{56}$ As is well-known, the zodiac signs have always been related to different features of the human body, and Louis Cruchet has identified close resemblances between Durand's scheme and the Conditionalist astrology proposed by Jean-Pierre Nicola. $^{57}$

In emphasizing the dynamic nature of psychic images and archetypes, and refusing the reduction of symbols to signs, Durand's brand of structuralism - if that is what it is - seems to offer a theory of symbols closer to the experience of astrologers. ${ }^{58}$ Durand was also the Jury Chief for Patrice Guinard's PhD thesis at the Sorbonne, and although Guinard was not influenced by him, Durand told him that in his book La Foi $d u$ Cordonnier he had attempted something similar. ${ }^{59}$

\section{Surrealism}

André Breton's name crops up only briefly in the interview, but he had an important influence on Lévi-Strauss. Lévi-Strauss had met Bréton and the Cuban surrealist painter Wifredo Lam on the boat which took them from Europe to Martinique, and credited Breton with opening his eyes to the

de l'Imaginaire: Derive autour de l'oeuvre de Gilbert Durand (Paris: Berg International, 1980).

${ }_{55}$ A. J. Greimas, Semantique Structurale (Paris: Larousse, 1966).

${ }^{56}$ For a discussion of Jung's views by one of his close associates, see Jolande Jacobi, Complex/Archetype/Symbol in the Psychology of C.G. Jung (Bollingen Series LVII) (Princeton: Princeton University Press, 1959), pp. 39-46.

${ }^{57}$ Louis Cruchet, Ethnoastronomie at traditions astrologiques (Paris: Publibook, 2009), pp. 161-179. He also cites Nicola as saying that human astral determinism is biological not psychological, see p. 165 .

${ }^{58}$ See Maggie Hyde, Chapter 4, 'The Symbolic Attitude', in Jung and Astrology (Aquarian/Thorsons, 1992), available at: http://www.maggiehyde.com/books/jung_sings.html [accessed 3 July 2016].

59 Email from Patrice Guinard, 1 Jun 2016. Guinard's thesis is entitled 'L'Astrologie, fondements, logiques et perspectives' (Paris, The Sorbonne, 1993). It is available on his website http://cura.free.fr, along with a list of other theses on astrology over the last 100 years: http://cura.free.fr/01authd.html. Gilbert Durand, La Foi du Cordonnier (Paris: Editions Harmattan, 1984)

Culture and Cosmos 
exotic hidden in the ordinary. ${ }^{60}$ In fact, the surrealist attitude of looking for the marvellous within the ordinary, and creating new perspectives by juxtaposing objects or images that were normally considered incongruent goes to the heart of the developing methods of anthropology in France during the $20 \mathrm{~s}$ and $30 \mathrm{~s} .{ }^{61}$ Surrealists too looked for inspiration among marginal areas of society, and Lévi-Strauss described the anthropologist as a Chiffonnier or rag-and-bone-collector. His famous use of the term bricolage in The Savage Mind, to describe the ways of thinking in nonindustrial societies, refers to the use of whatever comes to hand as a means of creating artefacts. ${ }^{62}$ The crossover between surrealism and ethnology accelerated among the émigrés in New York, but it began well before in Paris, as evidenced by the contributions of the surrealist Michel Leiris and the anthropologist Marcel Griaule to the short-lived arts magazine Documents in 1929-30. And Leiris set off in 1931 as the secretary on Griaule's 2-year Dakar-Djibouti expedition, which led to huge interest among the French public when it returned and its artefacts and recordings were displayed in an exhibition.

Leiris later became an anthropologist himself, and wrote La Langue Secrète des Dogons de Saga (1948), while Griaule is well-known for his studies of the cosmology of the Dogon people in Mali. ${ }^{63}$ Griaule and Dieterlen's work was aimed at the discovery of the esoteric, the cosmogonic secrets of the Dogon, another interesting theme in common with astrology. ${ }^{64}$

CLS developed his interest in surrealism from his close relations with André Breton and Max Ernst during their exile in New York, especially through the opportunities they had to buy Indian masks from the Pacific Northwest coast. One of CLS's last works was The Way of the Masks. ${ }^{65}$ It

\footnotetext{
${ }^{60}$ Lévi-Strauss, 'Voix Off', p. 30.

${ }^{61}$ James Clifford, 'On Ethnographic Surrealism', Comparative Studies in Society and History 23, no. 4 (October 1981): pp. 539-564, p. 542.

${ }^{62}$ Wilcken, The Poet, p. 184; and Claude Lévi-Strauss, The Savage Mind (London: Weidenfeld and Nicolson, 1966), p. 17

${ }^{63}$ Michel Leiris, La Langue Secrète des Dogons de Sanga (Paris, Editions JeanMichel Place, 1948). Marcel Griaule, Conversations with Ogotemmeli: an introduction to Dogon Religious Ideas (London: International African Institute, Oxford University Press, 1970).

64 James Clifford, The Predicament of Culture (Cambridge, MA: Harvard University Press, 1988), p. 85.

${ }^{65}$ Lévi-Strauss, The Way of the Masks, trans. Sylvia Modelski (1982: Seattle: University of Washington Press, 1988).
} 
can be argued that the interest of anthropologists in Amerindian and African art in turn influenced the surrealists, who were concerned to break out of what they regarded as the prison of conventional rationality.

And in fact there are very surreal passages in some traditional myths, as this extract shows. In The Origin of Table Manners Lévi-Strauss describes a Guianan myth (M524) about the origin of the anus.

In the beginning neither men nor animals had anuses but excreted through their mouths. One day a disembodied anus sauntered among them, farting in their faces and then escaping. But they hunted him down, cutting him up in pieces and sharing him out among all animals - bigger or smaller, in accordance with the size of an orifice today. ${ }^{66}$

The crossover with anthropology has been examined by a number of writers, including James Clifford, James Hollier and J. Michael Dash. Hollier concluded that Clifford had exaggerated the connection, because except during the period of Documents, there was never a group of surrealist-anthropologists. ${ }^{67}$ Dash draws attention to the important influence of surrealism on the Martinican poet and campaigner for black liberation, Aimé Césaire, which was reinforced by André Breton's arrival in Martinique in 1941, accompanied by Lévi-Strauss, and when Breton later returned and became involved in Haitian politics. ${ }^{68}$ Pierre Mabille was another key figure in the Caribbean, and one who met André Barbault. ${ }^{69}$ Mabille was a doctor, anthropologist and diplomat as well as being an astrologer.

In 1968 Lévi-Strauss gave an interview to Claude Courtot, for the surrealist magazine L'Archibras, during which he responded to the following questions:

As the father of structuralism, are you happy with your offspring? Putting ethnography aside, what do you think of incest? As a Bororo tribesman, how

\footnotetext{
${ }^{66}$ Cited by Wilcken, The Poet, p. 292

${ }^{67}$ See Dennis Hollier, 'Surrealism and its Discontents', 2007, available at http://www.surrealismcentre.ac.uk/papersofsurrealism/journal7/acrobat\%20files/ar ticles/Hollierpdf.pdf [accessed 20 June 2016].

68 J. Michael Dash, 'Le Je de l'autre: Surrealist Ethnographers and the Francophone Caribbean', L'Esprit Createur 47, no. 1 (2007): pp. 84-95.

${ }^{69}$ André Barbault, interviewed by Fabrice Pascaud in 2007, in L'Astrologue 161 (2007), Special Issue. This issue seems impossible to find in libraries, and the publishers did not respond to inquiries, but the whole interview is available in Italian in 3 parts on the website www.enzobarilla.eu
}

Culture and Cosmos 
would you respond to a visit by M. Lévi-Strauss? Do you have any hopes for space travel? ${ }^{70}$

Lévi-Strauss entered into the spirit of the interview and replied to the second question in terms that no public figure would employ today. But none of this implies that Lévi-Strauss was willing to embrace surrealisme sauvage in the style of Georges Bataille and Michel Leiris: that was a step too far, as was belief in astrology. In 1954 Lévi-Strauss had been involved in a virulent controversy with Roger Caillois, one aspect of which was the latter's claim that Lévi-Strauss had been influenced by Dada and Surrealism, which Lévi-Strauss rejected in a crushing 30-page response in Les Temps Modernes. ${ }^{71}$ And according to Patrick Wilcken, Lévi-Strauss became suspicious even of modern art movements including Cubism:

'while primitive art was a collective enterprise embedded in the societies in which it was produced and fused with their ritual and religious lives, Cubism was a contrived escape into an individualised aesthetic world'. ${ }^{72}$

Despite Barbault's friendship with Breton, in an interview in 2007 he said that he had not been much influenced by surrealism, although he then went on to tell an anecdote about Breton. ${ }^{73}$ When Barbault had suggested to Breton, that astrological cycles involving Jupiter and Uranus as well as Saturn and Pluto were related to the development of Dada and hence surrealism, and to the first world war in 1914, Breton apparently rejected the idea, saying that Surrealism was not determined by the planets. ${ }^{74}$ This makes an interesting contrast with Breton's own interest in the synodic cycle of Saturn and Uranus, which he noted in the birth charts of his most esteemed antecedents, Gérard de Nerval (22 May 1808) and Artur Rimbaud (20 October 1854), and contemporaries Louis Aragon (3 October 1897), Paul Éluard (14 December 1895) and himself (19 February 1896).

${ }^{70}$ Lévi-Strauss ,'Voix Off, Claude Courtot entretien avec Claude Lévi-Strauss', pp. 27-31.

${ }_{71}^{71}$ Loyer, Lévi-Strauss, pp. 404-408.

${ }^{72}$ Wilcken, The Poet, p. 236.

${ }^{73}$ Tessel M. Baudoin, Surrealism and the Occult: Occultism and Western Esotericism in the Work of André Breton (Amsterdam: Amsterdam University Press, 2014), pp. 109-111.

${ }^{74}$ Barbault, 'Entretien', p. 2, available at: www.enzobarilla.eu/Intervista_Barbault_Pascaud_II_Parte.pdf_[accessed 1 July 2016]. 
Baudelaire, he noted, was born at the time of a Uranus-Neptune conjunction (9 April 1821). In two of these cases Saturn and Uranus were quite far apart, (Rimbaud 30 degrees, and Nerval 16 degrees), more than would be accepted as conjunctions by most astrologers. And if artists could be identified astrologically so easily we should include Joseph Goebbels (29 October 1897), who indeed obtained a $\mathrm{PhD}$ for a thesis on a romantic writer, but was known to detest modern culture and was a little lacking in surrealist humour. ${ }^{75}$ Breton went to the length of changing his own birth date by one day, so as to have the Sun in Aquarius instead of Pisces, although there may also have been other personal reasons for this. ${ }^{76}$

A belief in the need for defamiliarisation is quite in tune with the surrealists' approach, and it was also an important feature of the Russian Formalist movement during the First World War, led by Viktor Shklovsky. Another member of this group was Roman Jakobson, who founded - in his first period of enforced exile - the Prague School of Linguistics. In New York Jakobson became one of the major acknowledged influences on LéviStrauss's linguistic structuralism applied to myth. ${ }^{77}$

Another feature of Breton's surrealist approach was the belief in attaining the unity of opposites through their art, which was also the purpose of myth in the view of Lévi-Strauss. This suggests a therapeutic aspect of surrealist art. And the surrealist belief in 'objective chance' by which the inner-outer dynamic was expressed through encounters that were pre-ordained rather than random, recalls the correspondences that are a central feature of astrology, as well as Jung's concept of synchronicity or an 'acausal connecting principle' ${ }^{78}$ Despite this, Jung, whose interests in astrology and alchemy were shared by the surrealists, was rejected by them as a reactionary and a fascist sympathiser. Freudian thought and especially Freud's view that sexuality was the basis of all action was still part of the central dogma of surrealism. ${ }^{79}$

\footnotetext{
75 Baudoin, Surrealism, pp. 109-111. For Goebbels, see Roger Manvell and Heinrich Fraenkel, Dr. Goebbels, his Life and Death (New York: Skyhorse, 2010).

${ }^{76}$ Baudoin, Surrealism.

${ }^{77}$ Hawkes, Structuralism, pp. 60-73.

78 Baudoin, Surrealism, p. 119. See also Nicholas Campion, 'Surrealist Cosmology, André Breton and Astrology', Culture and Cosmos 6, no. 2 (Autumn/Winter 2002): pp. 45-56, available at www.cultureandcosmos.org.

${ }^{79}$ Baudoin, Surrealism, p. 143.
}

Culture and Cosmos 
Breton was the leader of the more rational wing of the movement, which valued academic study and even attempted to assess objective chance by distributing a questionnaire. ${ }^{80}$

Barbault knew the psychoanalyst René Allendy who was the source of his group's interest in connections between psychoanalysis and astrology 'at the end of WW2 ${ }^{81}$ This is interesting because over a decade earlier in 1933, Allendy had organised a series of lectures at the Sorbonne on 'pensee magique', which may well have been catalytic in promoting the interest of the surrealists in the common ground with anthropology, based on dreams, magical thought and neuroses. ${ }^{82}$ Breton's surrealist group's rapprochement with the occult did not really begin until about 1943, but their studies of works by Sir George Frazer and Lévy-Bruhl as well as Freud was certainly a pre-disposing force. Another important feature in tune with social anthropology was that the surrealists followed Lévy-Bruhl in rejecting the idea, espoused by Freud and Frazer, that primitive thought was inferior: to them however, unlike Lévi-Strauss, it was more than just different - it was superior to modern western thought.

This attitude, of course, derived from the surrealist desire for a revolution in consciousness in the west, whose reliance on rationality had, in their view, been responsible for the devastation of the 1914-18 war. Myth too became important to them, and in 1935 Breton gave two lectures in Prague in which he put forward the necessity for a new collective myth in western society, whose development would naturally be the task of the surrealists. ${ }^{83}$ The journal Minotaure was the vehicle for many publications about myth, including two articles by Jacques Lacan. ${ }^{84}$

So, all in all, we can see family resemblances between surrealism, occultism, astrology, and nascent social anthropology, but also a lot of family squabbles, and in the end the relevance of surrealism to the scientific study of culture diminished, while remaining stronger in the arts and also in post-colonial politics in the Caribbean.

The motivations of the editor of L'Astrologue for contacting LéviStrauss are not easy to analyse, but he was part of a group of intellectuals in Paris during the 1960s which included psychologists - even Jacques

${ }^{80}$ Baudoin, Surrealism, p. 119.

${ }^{81}$ Barbault, The Value, p. 168 and footnote 81.

${ }^{82}$ Baudoin, Surrealism, p. 121.

${ }^{83}$ Baudoin, Surrealism, p. 123; and see André Breton, Manifestoes of Surrealism, trans. Richard Seaver and Helen R. Lane (Ann Arbor, MI: Ann Arbor Paperbacks, 1972).

${ }^{84}$ Baudoin, Surrealism, p. 126. 
Lacan on one occasion - and artists, and he later interviewed André Breton for another issue of the same magazine. ${ }^{85}$ At least one member of this circle, the astrologer and Tarot reader Fabrice Pascaud, was a member of the reconstituted group of surrealists during the period 1979-84, but he has not responded to requests for information. Another indication of the overlap of Barbault's interests with surrealism, despite denying its influence on his work, is an interview that he did in 1973 with Guy Michaud, a literature professor who has written about surrealism and published a book, Le Visage Interieur: pour une anthropologie de l'ecrivain, in which he used the planetary archetypes and personality psychology. In his interview with Barbault, Michaud states that he used astrology explicitly in his teaching. ${ }^{86}$ It is interesting that Barbault attempts a similar classification to Michaud's, to whom he refers very briefly, but of painters instead of writers. ${ }^{87}$

\section{The way astrologers work}

At the end of the published interview Lévi-Strauss proposed a joint study of astrologers' works, with a view to understanding how they think. According to Dr Nicola the suggestion was not pursued, because 'there are as many astrologies as there are astrologers, and most of them are egocentric and individualist' ${ }^{88}$ But in the last 20 years several theses have been completed which involve different approaches to exactly this question. I hope it will be useful to cite some examples. ${ }^{89}$

The thesis which looks most closely at what astrologers do in a consultation is Kirsten Munk's, where she quotes a large number of astrologers discussing their methods.

The well-known astrologer Liz Greene is quoted as saying she has no idea how astrology works, but views it as divination, and says 'Everything is connected, the universe is alive.' She also mention's Jung's concept of the quality of a moment in time..$^{90}$ Bernadette Brady, whose background is in biological research, talks of escaping scientific reductionism and says

\footnotetext{
${ }^{85}$ See Intervista, Parts 1 and 2, www.enzobarilla.eu [accessed 1 July 2016].

${ }^{86}$ Barbault 'Entretien avec Guy Michaud', L'Astrologue 21 (Spring 1973), pp.1-5.

${ }^{87}$ Barbault, Value, p. 232-249.

${ }^{88}$ Jean-Pierre Nicola, email to Graham Douglas, 21 May 2016.

${ }^{89}$ A number of such theses are available on Patrick Curry's website, available at www.the9thhouse.org.

${ }^{90}$ Kirstine Munk, Signs of the Times, Cosmology and Ritual Practice in Modern Western Astrology (PhD thesis, University of Southern Denmark, Odense, 2007), p. 154.
}

Culture and Cosmos 
that 'astrology translates a dialogue with the cosmos'. ${ }^{91}$ John Wadsworth emphasizes the ritual element of what he does, taking time to be wellprepared to enter a different state of consciousness during which he 'asks a spirit guide to watch over the consultation' ${ }^{92}$

Again, Greene describes rare occasions when a deep rapport was established with a client and the transformative moment became very intense, saying that it happens very quickly with astrological symbols, in comparison to normal counselling work. ${ }^{93}$ The astrologer Steven Forrest speaks of being overtaken by the archetypes which speak through him. ${ }^{94}$ Munk then goes on to describe the effects of a consultation on clients with many transcripts from her conversations, as Vilhena did with astrology students in Brazil. ${ }^{95}$

In his discussions Vilhena noted a number of recurring themes when he inquired why students were interested in astrology, including a search for meaning, a need for spirituality free from the rigid constraints of either Catholicism or Freudian psychoanalysis, and as a means of developing and negotiating their identity in modern society. Some of his informants had experimented with Candomblé practices with varying degrees of commitment.

Clearly the practice of astrology has moved on from the typical 'find your personality and your destiny', and become more in tune with postmodern and post-structuralist thinking without ever incorporating these analyses into its textbooks. When we consider the way that astrologers have attempted to bring the chart features in line with the Jungian archetypes we have already seen that there is a good deal of confusion. As Gras points out, the number of archetypes is potentially limitless, so any correspondences with an astrological chart will not be convincing. ${ }^{96}$

So if Lévi-Strauss had been able to proceed with his suggested project of analysing astrological interpretations he would likely have found himself dealing with material closer to literature than to myth, a difficult situation for the Lévi-Strauss of 1969, as illustrated by the sardonic response he made to Roland Barthes' Structuralist criticism. Given the current saturation of psychological astrology with Jungian psychology one

${ }^{91}$ Munk, Signs, p. 162.

${ }^{92}$ Munk, Signs, p. 182-183.

${ }^{93}$ Munk, Signs, p. 194.

${ }^{94}$ Munk, Signs, p. 197.

${ }^{95}$ Vilhena, World, Chapter 3, pp. 87-122.

${ }^{96}$ Vernon W. Gras, 'Myth and the reconciliation of oppositions: Jung and LeviStrauss', Journal of the History of Ideas 42, no. 3 (1981): pp. 471-488.

Culture and Cosmos 
wonders how he would have responded to analysing the readings of astrologers.

And inevitably Lévi-Strauss would have found multiple astrologies, perhaps related to their social environments. In the postmodern context of Rio de Janeiro, Vilhena noted that while some embraced Jungian astrology as a liberation from rigid Catholic spirituality, others went the opposite way, towards The Tradition espoused by René Guénon. ${ }^{97}$ This splitting pattern may be a general phenomenon; it calls to mind what Chude-Sokei observed in Jamaica, where Rastafarianism sought a return to roots culture, while Rap's techno-poetics embraced a Creolized future. ${ }^{98}$

In a commentary on Jung and Lévi-Strauss, Gras says:

If it is true that we can never escape from the "hermeneutical circle" or from culture viewed as a "chain of signifiers" which will never break through to their referents, that unmediated Nature is a phantasm, that Culture is a manmade horizon wherein both I and the Other find and transform our identities, that Truth is a matter of convention and that there is no neutral "objective" ground which can adjudicate rival truth claims, then how does one initiate cultural change and decide between alternatives in order to legitimize them? ${ }^{99}$

He continues,

One cannot legitimate a specific change by referring it to the call of Being or to the general exercise of human freedom, except in the rhetorical manner of every reformer and prophet in the past. If the distinction between myth and science, traditionally expressed as between the false and the true, no longer holds and scientific descriptions of Nature receive their legitimation only from cultural beliefs and practices, then the sciences of today become the myths of tomorrow. No longer do "privileged representations" exist anywhere. The only standard or guide left to us is pragmatic. ${ }^{100}$

And as Vilhena concludes: 'Contrary to the theoreticians of occultism, it can be seen how astrology truly becomes a vehicle that expresses and problematizes the tensions of [modern] values themselves, even while apparently denying them'. ${ }^{101}$

\footnotetext{
${ }^{97}$ Vilhena, World, pp. 164-165.

${ }^{98}$ Louis Chude-Sokei, The Sound of Culture: Diaspora and Black Techno-Poetics, (Middletown, CT: Wesleyan University Press, 2016), pp. 143, 161, 181.

${ }^{99}$ Gras, Myth, p. 487.

${ }^{100}$ Gras, Myth, p. 487.

${ }^{101}$ Vilhena, World, p. 187.
}

Culture and Cosmos 


\section{Acknowledgment}

I would like to acknowledge the help of Trudie Charles at the Astrological Association Library for supplying me with scans of articles which are hard to locate elsewhere. 